\title{
Meanings and significance attributed by people with HIV/aids to their lives with this virus/disease
}

Significados e sentidos atribuídos por pessoas com HIV/aids sobre a convivência com este vírus/doença Significados y sentidos atribuidos por personas con VIH/SIDA sobre la convivencia con ese virus/enfermedad

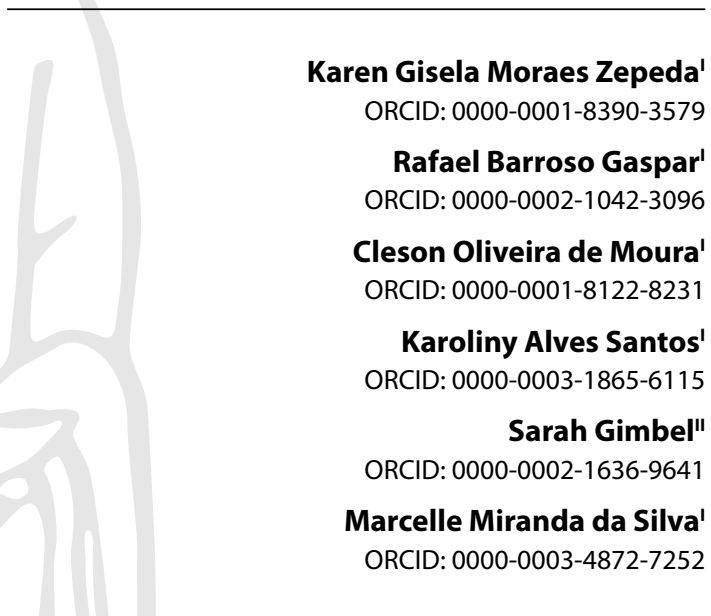

'Universidade Federal do Rio de Janeiro. Rio de Janeiro, Rio de Janeiro, Brazil. "University of Washington. Seatle, Estados Unidos da América.

How to cite this article: Zepeda KGM, Gaspar RB, Moura CO, Santos KA, Gimbel S, Silva MM. Meanings and significance attributed by people with HIV/aids to their lives with this virus/disease.

Rev Bras Enferm. 2022;75(3):e20201323. https://doi.org/10.1590/0034-7167-2020-1323

Corresponding author: Marcelle Miranda da Silva E-mail: marcellemsufrj@gmail.com

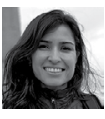

EDITOR IN CHIEF: Antonio José de Almeida Filho ASSOCIATE EDITOR: Hugo Fernandes

Submission: $12-30-2020$

Approval: 03-31-2021

\begin{abstract}
Objectives: to understand the meanings and significance attributed by people with HIV/aids to the process of living with this virus/disease. Methods: qualitative and exploratory study, carried out in Rio de Janeiro, Brazil. The Grounded Theory and the Symbolic Interactionism were used. Data were collected in a semistructured interview and through non-participant observation, from August 2017 to May 2018. 29 patients participated. Results: living with HIV/AIDS is a social phenomenon in which it is not possible to disconnect the process of adapting to the disease from the social relations one (re)constructs during life. It also involves stigmatization, rejection, and isolation. Final Considerations: understanding the meanings of this process is a positive influence for proactive behavior and resilience, not only in regard to the care concerning the presence of the virus and the uninterrupted need to adhere to medication, but also in the way to deal with the social values that reproduce previous models, which, in turn, can help improve self-knowledge.

Descriptors: HIV; Acquired Immunodeficiency Syndrome; Comprehensive Health Care; Patient-Centered Care; Symbolic Interactionism.
\end{abstract}

\section{RESUMO}

Objetivos: compreender os significados e sentidos atribuídos por pessoas com HIV/ aids sobre o processo de conviver com este vírus/doença. Métodos: estudo qualitativo, exploratório, realizado no Rio de Janeiro, Brasil. Utilizou-se a Teoria Fundamentada nos Dados e o Interacionismo Simbólico. Os dados foram coletados por entrevista semiestruturada e observação não participante, entre agosto de 2017 e maio de 2018. Participaram 29 pacientes. Resultados: conviver com o HIV/aids é um fenômeno social, onde não há possibilidade de desvincular o processo de adaptação à doença das relações sociais (re)construídas ao longo da vida, ainda acompanhado de estigmatização, rejeição e isolamento. Considerações Finais: compreender os significados deste processo de convivência favorece o comportamento proativo e a resiliência, não só em relação aos cuidados diante da presença do vírus e à necessidade ininterrupta de aderir aos medicamentos, mas também ao lidar com os valores sociais que reproduzem modelos, que em contrapartida, podem ajudar no autoconhecimento. Descritores: HIV; Síndrome de Imunodeficiência Adquirida; Assistência Integral à Saúde; Cuidado Centrado no Paciente; Interacionismo Simbólico.

\section{RESUMEN}

Objetivos: comprender los significados y sentidos atribuidos por personas con VIH/SIDA sobre el proceso de convivir con ese virus/enfermedad. Métodos: estudio cualitativo, exploratorio, realizado en Rio de Janeiro, Brasil. Utilizado la Teoría Fundamentada en los Datos e Interaccionismo Simbólico. Datos recolectados por entrevista semiestructurada y observación no participante, entre agosto de 2017 y mayo de 2018. Participaron 29 pacientes. Resultados: convivir con VIH/SIDA es un fenómeno social, en que no hay posibilidad de desvincular el proceso de adaptación a la enfermedad de las relaciones sociales (re)construidas durante la vida, aún acompañado de estigmatización, rechazo y aislamiento. Consideraciones Finales: comprender los significados de ese proceso de convivencia favorece el comportamiento proactivo y resiliencia, no solo cuanto a cuidados delante la presencia del virus y la necesidad continua de adherir a medicamentos, pero también al lidiar con los valores sociales que reproducen modelos, los cuales, en contrapartida, pueden ayudar en el autoconocimiento. Descriptores: $\mathrm{VIH}$; Síndrome de Inmunodeficiencia Adquirida; Atención Integral de Salud; Atención Dirigida al Paciente; Interaccionismo Simbólico. 


\section{INTRODUCTION}

Considering the stigma involved in the sociocultural representation of HIV/AIDS and its influence on the process of social and group integration, the process of living with this virus/disease brings psychic distress in its wake. A lack of safety results from physical changes, oportunistic infections, adverse reactions to medication, the presence of other chronic diseases, social stigma, loss of autonomy, and depression ${ }^{(1)}$. As a result, this condition affects all dimensions of the life of the person, with a strong impact on their interpersonal relations and lifestyle, since the negative perspective of living with this virus/disease may affect the quality of the treatments and the outcomes related to the state of health of these people ${ }^{(2-3)}$.

With the advent of the combined antiretroviral therapy, and its free dispensation by the Brazilian government since 1996, it became possible to stabilize some symptoms of the disease, which led to an increased life expectancy, partly disassociates the person with HIV/AIDS from the stigma of having a "death disease". However, despite the scientific advances to the improvement of their quality of life, many people with HIV/AIDS (PWHA) still do not show ideal results for their state of health ${ }^{(4)}$. The stigma associated with this virus/disease is still an individual and systemic barrier for care, strongly represented by the lack of social support, knowledge, and to a limited awareness about HIV and poverty ${ }^{(5)}$.

To confront this social stigma and the other adversities that result from the HIV infection, especially those related to its chronic nature and its instable course, resilience, as a form of positive adaptation or of resisting adversities, has been an important protective individual strategy and an opportunity for interventions to improve health outcomes, considering not only the control of HIV, but also the prevention of the transmission of the virus in society, with the objective of reducing or eliminating the epidemi $c^{(6-8)}$.

As a result, the stigmatizing and socioeconomic conditions that affect people with HIV/AIDS point out the need for integral health care through a continuous monitoring and an interdisciplinary approach to the biopsychosocial factors that can have a negative influence on the conviviality with this virus/disease, mental health, and quality of life.

As a result, this study asks: What are the meanings and significance attributed to people with HIV/AIDS to the process of living with this virus/disease?

\section{OBJECTIVES}

To understand the meanings and significance attributed by people with HIV/AIDS to the process of living with this virus/disease.

\section{METHODS}

\section{Ethical aspects}

This project was approved by an ethical appreciation from the proponent and co-participant institutions in February 2017. All participants signed the Free and Informed Consent Form and had their anonymity preserved. The interviews were identified using the letter E (for the Portuguese word for "interviewee"), followed by a number indicating the order in which they were carried out (E1, E2...).

\section{Type of study and theoretical-methodological references}

Qualitative, exploratory research, using the Consolidated Criteria for Reporting Qualitative Research (COREQ) checklist to guarantee its methodological validity.

The theoretical framework used was the symbolic interactionism (SI), while the methodological framework was the grounded theory (GT). The base of the SI involves the capacity a person has of reflecting on themselves, perceiving or understanding themselves in the role of the other and triggering their social selves, which emerges and develops in a context represented by society, where people and world may not be understood in isolation, but through a constant, dynamic, and never-ending transmutation. The self involves two separate analytical phases: the "I" is the impulsive tendency of the individual; the "Me" represents the other, generalized ${ }^{(9-10)}$.

Living in constant interaction, people can construct, deconstruct, and create new circumstances and actions according to the meanings they attribute to each social act, due to the symbolic capacities of the human being ${ }^{(9-11)}$. As a result, is essential to understand that individuals know of their world and what they believe is important.

In the GT, the concepts are constructed by the participants of the research, who attempt to explain and generate meaning from their experience and lives, both for the researcher and themselves. The product of this construction is called "knowledge", which, despite not being a mirror of the world, helps us understand it.

The relationship between GT and SI may be connected to the study of the aspects of human behavior that result from experience, that is, to the way in which people define the events or reality and how they act in relation to their beliefs ${ }^{(12-13)}$.

\section{Study setting}

This study was developed in a specialized hospital for the attention of clients with HIV/AIDS, in the city of Rio de Janeiro, Brazil. The settings were the clinical hospitalization sector and the outpatient clinic. Two nursing wards, one masculine and one feminine, were designed to attend those with HIV/AIDS. Each had 15 beds, 1 of which was isolated, and 1 of which was destined for intensive care. The outpatient clinic had eight rooms, where people with HIV/AIDS were attended, as well as patients of other specialties.

\section{Study participants}

In regard to the participants of the study, it must be mentioned that the concept of theoretical sampling emerges in the GT as associated with the process of data collection, in order to "search places, people, or events that improve the identification of changes in concepts, also generating denser categories, properties, and dimensions, according with the needs for information found in the development of the research"(13). Therefore, throughout the clinical process of data collection and simultaneous analysis of data until reaching data saturation, two groups were formed from the sample, including 29 participants (Chart 1). 
Chart 1 - Composition of the sample groups

\begin{tabular}{|c|c|c|}
\hline Hypotheses & Groups & $\begin{array}{l}\text { Leading } \\
\text { question }\end{array}$ \\
\hline $\begin{array}{l}\text { The person who was hospitalized } \\
\text { due to clinical complications from } \\
\text { AIDS, for many factors, may not } \\
\text { use the medication prescribed } \\
\text { and not take other types of care } \\
\text { of their health, leading to further } \\
\text { hospitalizations -- it stands out that } \\
\text { this first hypothesis, in addition } \\
\text { to determining the object of this } \\
\text { study, was related to the outcome } \\
\text { of the study, concerning the man- } \\
\text { agement of nursing care for HIV/ } \\
\text { AIDS from palliative and hospital } \\
\text { perspectives }{ }^{(14)} \text {. }\end{array}$ & $\begin{array}{l}17 \text { patients } \\
\text { hospitalized } \\
\text { due to clinical } \\
\text { complications } \\
\text { from AIDS }\end{array}$ & \multirow[t]{2}{*}{$\begin{array}{l}\text { What does } \\
\text { care mean } \\
\text { to you? }\end{array}$} \\
\hline $\begin{array}{l}\text { Patients attended in the outpatient } \\
\text { clinic, with no recent hospitaliza- } \\
\text { tion history, follow a routine of care } \\
\text { that could be related to meanings } \\
\text { that are different from those of the } \\
\text { patients who have the disease and } \\
\text { are frequently hospitalized. }\end{array}$ & $\begin{array}{l}12 \text { patients } \\
\text { monitored in } \\
\text { the outpatient } \\
\text { clinic }\end{array}$ & \\
\hline
\end{tabular}

All adult patients with HIV/AIDS registered in the hospital were included. Patients who, according with an evaluation from the health team, had any cognitive condition that made it impossible to answer the questions, were excluded. Therefore, to invite patients who were potentially adequate for participation, the professionals were consulted. They were also asked about information on the diagnosis of the infection and the reason for the hospitalization (in the case of the nursing wards), always considering the criteria mentioned above.

\section{Data collection and organization}

The data were collected in a semistructured interview from August 2017 to May 2018. The interviews were individual and in-person, recorded in audio, and lasted for a mean of 20 minutes.

Data collection was carried out by a single researcher who was going through her doctorate studies. She had experience with the interview technique and had established a rapport with some participants in a previous research.

The patients hospitalized were interviewed at bedside (the beds were individualized, separated from the ward by walls and curtains). The patients from the outpatient clinic were interviewed in private rooms in the clinic itself. There was no one else with the participant in any of the interviews.

Before the interviews were conducted, the demographic profile of the participants was characterized according to the variables "age" and "sex". In addition to the early question from the interview in Chart 1, circular questions were asked to further the understanding of the phenomenon.

The degree of saturation needed to develop the conceptual body of the categories that gave support to the substantive theory was obtained through theoretical saturation and inductive thematic saturation, using the theoretical sample and the number of codes generated, respectively ${ }^{(15)}$.

\section{Data analysis}

The data was coded by two researchers, following the stages: open coding, axial coding, and integration. The open coding was the analysis, line by line, of the raw data, which was compared and conceptualized using words that expressed action, according with the questions: "What is this? What does it represent? What is happening here?"This made possible to identify preliminary codes, their properties and dimensions ${ }^{(12)}$.

The axial coding, in turn, is "marked by the inductive-deductive movement, which requires the researcher to have theoretical sensitivity and to reflect", as they search answers for the questions "Why? In what way? Where? When? How?" At this point, the preliminary data found in the open coding were regrouped in the inductive process, to form explanations about the investigated phenomenon and make it possible to generate conceptual codes, in the form of categories ${ }^{(12)}$. In this stage, the paradigm was used as an analytical tool, allowing one to organize the data as conditioning factors, action-interaction strategies, and consequences or results.

In this study, which is an excerpt from a doctorate thesis, conditional factors were developed, answering questions about the phenomenon under investigation, related to why, when, and how, in order to understand the meanings people attribute to occurrences, in addition to showing the reasons and explanations the participants gave for their actions (action/interaction) in regard to these occurrences.

In the last stage of the analysis - integration -, the categories and subcategories were refined to delimit the theory, which was organized according with the elements of the paradigmatic model, and then, the raw data received an abstract representation ${ }^{(13)}$.

\section{RESULTS}

In regard to their age group, 11 patients (38\%) were from 40 to 49 years old; 9 (31\%) from 30 to $39 ; 4$ (14\%) from 18 to $29 ; 3$ (10\%) from 50 to 59; and 2 (7\%) from 60 to 69. Regarding sex, 17 participants (59\%) were male; and 12 (41\%) were female.

The category detailed in this study, represented by the conditioning factors related to the phenomenon investigated, is formed by five subcategories (Chart 2).

This category includes the meaning the patients gave to the form in which they react to the stimuli from the environment where they live, where they establish meanings, which leads them to attribute meanings to things and people with whom they interact in society.

They, consequently, develop, as a result of this interaction, actions to confront the situation, when resilient; negative actions that they already did or start to do; actions that lead them to get closer to "normality", to feel "accepted" in society; actions such as taking the medication from the antiretroviral therapy (ARVT) to stay alive; actions that, often, lead them to abandon the medication when they feel they are not diseased, when they are immunologically quiescent, and other diseases are absent; and reactions to the prejudicial effects their health state, affected by the HIV/AIDS infection, have on their self-image. 
Chart 2 - Description of the category and its subcategories

Phenomenon: reacting to the infection from HIV by perceiving the danger of its clinical manifestations.

Category 1:

Attributing meaning

to the process of

living with the virus/

disease according to

one's interaction with

oneself and to the

people around with

or without HIV.
Subcategory 1.1: needing networks of health care and social support to promote resilience and prevent health issues

Subcategory 1.2: Reproducing the discourse related to the concept of care

Subcategory 1.3: attributing the meaning of care to the attention of basic human needs and to the regular use of antiretroviral therapy.

Subcategory 1.4: feeling fluctuations in the symptoms o the disease, its impact, and the stigmas to self-image and quality of life

Subcategory 1.5: not caring for oneself when feeling well or when the disease is absent or nonspecific.

\section{Subcategory 1.1 - needing networks of health care and social support to promote resilience and prevent health issues}

This subcategory shows the fragilities and the demand for the formation of health networks that can attend to physical or psychic needs, considering the stigma these patients perceive from the people in their social lives.

\begin{abstract}
Many people asked me if I had AIDS. I won't go to your house anymore. It's something that's not worth talking about, it hurts me. And worse, it comes from my family. (E27)
\end{abstract}

I caught it from my ex-boyfriend. He only told me after we broke up [...]. When I see someone hurt I always want to care for them, I don't get sick when I see it or anything, but today, if I need to help, I feel afraid. I think twice [...]. I'm afraid others will catch it [crying]. (E25)

That prejudice where they comment, gossip, it's there. So, since we managed to finish this, she [the mother] gives me strength and we think it's best to keep it between us, not to tell anyone else. (E19)

\section{Subcategory 1.2: Reproducing the discourse related to the concept of care}

This subcategory shows that most patients answered that the meaning of the word "care" is related to the process of living with HIV/AIDS. The meaning was part of the thought about what society sees as correct, so they do not seem to be sick, following norms from the biomedical field that include eating well, taking medication, and adopting, in general, healthy habits.

However, some interviewees related that they suffer with the infection, even though their discourse is positive, apparently approved by all in society. In the extract from the interview with E12, for instance, it is possible to perceive a duality in the statement: he says that he was not physically ill during the interview and reports to feel optimistic about the maintenance of his physical health state; however, he reveals a phase that is emotionally and psychically shaken.

I take my image in consideration a lot, because I'm really vain, you know? I like being someone healthy, I'm an athlete, I do bodybuilding, so I think that care comes from health, from vanity [...] Every three months, I like to have blood tests to know how the internal part of my body is, appearance is not enough. I like to be well, you know? Even psychologically, so I can lead my life well knowing [...] But in regard to people, I can't anymore, I mean, sexually. I don't know if its psychological, if I need therapy, I don't know. But the thing is I can't anymore [...]. It's like someone took my heart out and threw it away. (E12)

We have to take care, or it'll mess our whole life. We have to do things right, to avoid going through what I went through. I didn't work for a year. I couldn't do anything. I try to always take the medication. I try to eat well. I work mostly at night, in the taxi, but I always have dinner, but sometimes I feel hungry and eat snacks. (E15)

\section{Subcategory 1.3 - attributing the meaning of care to the attention of basic human needs and to the regular use of antiretroviral therapy.}

This subcategory shows an overview about the meaning of care in having HIV and interacting with other people, with or without the virus. Attending to primary human needs refers to the vital need for certain processes, such as sleeping, eating, having an occupation, having a relationship, having a place to live, leisure, self-care, etc.- These processes make it possible to address the activities of daily living, to which patients attribute meanings and concepts that affect the way in which they deal with routine issues and with the people around them.

To care is to look after, right? It's love, it's worrying for the person, always encouraging good things, saying good words, positive ones [...]. I care for myself, I get up early, attend to my obligations, ride a bike, care for others, help caring for others. I care for my health, leat well, at the right times, I like to go out. I live! I like living! (E10)

I've always been well cared for here. You know? The nurses come, they ask me how I am. That thin one came here to say: "Whatever you need you just have to call" [...]. They give me medicine, all normal, what they do for the patients. I get very attached. When I go away, leven cry. (E4)

I go to the doctor whenever I can. If anything happens, I get afraid and run to the doctor [...]. I try to hold back, I don't drink how I used to. First, because I take the medication, so you can't do it, it's not very good. Second, I'm calmer. Quieter. (E21)

The use of the ARVT is is a new responsibility in the life of the PWHA, in addition to daily care, which implies a process of meaning about the power of medication to prolong the life of those who have HIV. The use of ARVT is not mandatory, but it is 
highly recommended. In this research, the patients reported how important it is to use it regularly, attributing meanings related to care in regard with living with this virus/disease.

I read the package insert of one of them [ARVT medication], it was huge. Basically, if you stop taking it, the virus gets stronger and you have to take more and more. And I worry because I'm a very forgetful person. I was taking vitamins and some days I forget. (E5)

Nonetheless, although the ARVT is recommended to avoid opportunistic infections, it has countless effects that negatively affect the lives of these people. The lifestyle of some patients influence the intake of antiretroviral medication.

I've been taking the medication for 17 years. Along these years, I stopped taking it twice, because I used drugs, marijuana and cocaine. Now I don't use them anymore, I' $m$ in the Narcotics Anonymous and I'm taking the medication again. (E7)

Every drug has its effect. And since this is a strong medication, there is a reaction. It's very important for people to know this is not just a pill. It's a drug you'll depend on and it has side effects. The esophagus grows, you hallucinate, sometimes you find yourself trying to catch bugs on the bed. (E4)

\section{Subcategory 1.4 - feeling fluctuations in the symptoms of the disease, its impact, and the stigmas to self-image and quality of life}

This subcategory shows the complex and varied reasons that can lead to hospitalizations and the fluctuations of symptoms that impact on the self-image and on the quality of life. Although these are subjective and personal, there is an important social construction.

I am a patient here since 2012. I left my house five years ago, I came back because of a rash, a bedsore, on the lumbar, I had to have it debrided, now I have skin cancer and I had a colostomy done, but still, I have spirit, strength, I'm determined to live. Because of the HIV I've had the Guillian-Barré syndrome, urinary infection, pneumonia, tuberculosis, you know? (E3)

All these lesions in my face, the HPV, all it's happening now. It shouldn't happen. Because in 12 years of treatment this never happened. I work with beauty. I can't work like this. (E11)

In fact, there is still prejudice, even today, according to the statements of E3:

At home, everything was separated, the plate, the spoon [...], the person [the mother] is old, so she only gets wrong information in the streets, then she separated everything. I tried to deal with the prejudice with my dog, because I gave it pieces of meat in the house, and the dog would eat them, and she didn't get thinner, she got fatter. So I said: "You see? The dog doesn't die". (E3)

\section{Subcategory 1.5 - Not caring for oneself when feeling well or when the disease is absent or nonspecific.}

This subcategory shows that, if, on one hand, it is difficult to live with the infection or disease using the ARVT, on the other, there are moments when the patient shows no signs or symptoms and decides to take actions with negative effects, which, often, they already took, regardless of being infected by HIV. These actions are understood as a slip.

I was taking it, but Kaletra is a medication you only take during pregnancy. Mine [ARVT scheme] used to be lamivudine and two others that didn't make me sick. So I told the doctor that I couldn't take the Kaletra anymore, that it made me vomit. Then the doctor said: "you take it for one more year." Then I said: "What? I doubt it [...]"; three years went by and I didn't take it [...]. I was on the "streets", walking the favelas, taking drugs, you don't even get a cold, you know. (E4)

But I tell you, from the bottom of my heart, I was talking about it these days [...]. Sometimes, I forget I have it [HIV]. Honestly. I know it exists, but it doesn't even seem that I got it, because I feel so good. Thank God! So it's fine. (E14)

\section{DISCUSSION}

The conditioning factors can locate and explain the actioninteraction between people considering the knowledge of the history of conditions and consequences of a certain reality, which, in the case of AIDS, is related to an epidemic permeated by cultural, social, political, biomedical, and economic dimensions, increasing the complexity of its dynamics ${ }^{(13)}$. Furthermore, the advance of the epidemic did not follow the psychosocial elements of care. It is necessary to consider the specificities and outcomes of the social life of the being infected by HIV/AIDS.

To understand the meanings that the patients attributed to living with HIV/AIDS, based on the SI, anchored in the pragmatism that is the base of the social constitution of one of its most important concepts, the self, this study made an attempt to reaffirm its basic principles, understanding that: the actions of the PWHAs are related to these meanings; and that they start from social interactions with people around them, with or without HIV, and can be controlled in an interpretative process used by them as they deal with things in their daily life, which involve changes in all aspects of their lives and imply the restructuring of the "I" and of the "Me"(10).

The social and epidemiological profiles of AIDS have undergone changes throughout time, and, even today, people who live with HIV/AIDS suffer prejudice due to the stigma that involves attitudes that are non-compliant with social rules at the time of contamination by the virus, considering the connection between the infection and certain behavioral profiles, such as the case of men who have sex with other men ${ }^{(16)}$. This takes place because part of society still reproduces these symbols.

The context, inherent to the interviewees, especially to hospitalized patients, since these are the ones that feel the manifestations of the disease, involves a constantly (re)formed process of selfknowledge, since, when they received the diagnosis of HIV, their lives changed, be it in the way they look at themselves, at their attitudes and daily choices, or in their interactions with people

From an interactionist perspective, the way in which individuals relate to one another contributes for the origin of identity processes, since relations are mediated by material or symbolic borders, which are also socially constructed and resignified by 
changes in social and historic contexts, such as the unstable course of the HIV/AIDS epidemic. The "I" is produced based on social interactions - dynamic and mutable -, rooted in a context that is charged with many factors that condition the influence of this production, which also includes the transmuting character of the epidemic ${ }^{(9-10,17)}$.

It stands out that the understanding of the meanings of the process of living with this virus/disease has been connected to the social reproduction of good customs, sharing the meanings constructed in society, according to which everything should be done systematically, including eating, sleeping and resting, using medication, all that is related to the care of the body. Although it may be common to expect not to be contaminated if said good customs are respected, once infected, the person who lives with HIV/AIDS starts to assume socially accepted behaviors, or makes statements to this effect, to maintain a good appearance and the non-specificity of the disease, often keeping the diagnosis in secrecy.

However, as they use adjectives such as "correct", "right", "healthy", the patients detail their own actions, such as caring for themselves in regard to what seems to be "right", which in certain moments may be the opposite of their actions.

It was possible to perceive, in the construction of the preliminary codes during the process of raw data analysis, the prevalence of the verb "have". The fact that they need this or that emerges as if there were a pre-defined recipe to be followed now that there is a new clinical condition. The "rightness" in everything they do now must take place regardless of their desires, considering the discourse of the participants based on the normative discourse of the health professionals themselves.

The fact that the "blaming" of the more vulnerable groups for spreading the AIDS epidemic is ingrained in society coincides with the statements of most patients interviewed, who revealed that they were infected by stable partners (although they are uncertain, since it is impossible to isolate all variables responsible for the infection or the time when it took place), even denying, at times, that their own behavior led them to acquire HIV.

With the development of the modern thought, the body, in René Descartes (1596-1650) starts to be analyzed as a machine, complex and divided in formative elements that generate and explain the current care practices of the modern scientific world. Human suffering, on the other hand, is increasingly connected to genetic, neurophysiological alterations, and the advances in medicine tend, more and more, to incorporate medicalization as a response to suffering. It stands out that, as in other advents of the pharmaceutical industry, the ARVT was responsible for the increased survival of people with HIV/AIDS, contributing to change the profile of the disease ${ }^{(18)}$.

In fact, people infected by HIV in the pre-ARVT era, that is, in the times where monotherapy/dual therapy had a survival expectancy of only 12.5 years. However, a person who becomes infected today in an industrialized country and uses ARVT (triple) has a life expectancy above 50 years of age ${ }^{(19)}$.

Perhaps this is the reason for the normative prescriptive discourse of medicalization as a primary action in the struggle against HIV/AIDS and the disease that stems from it. However, the predominant health model has overvalued the biological conception, privileging the disease instead of strengthening the life process of social actors.

This is why it is important to understand the meanings that each PWHA attributes to the process of living with this virus/ disease, since they indicate that actions-interactions should confront or overcome adversities, such as those triggered by social stigma and prejudice, which are directly related to the better or worse control of the state of health, as well as to that of the epidemic itself $f^{(5-6)}$.

Although interactionist studies are not limited to examining the individual behavior, the results pointed at the role of the social conduct of a group of people, relations of the PWHAs among themselves, as well as that of the PWHAs with people with no HIV. The origin of the self involves relations of power, expressed by mechanisms of social control and by the existing social roles, constructing meanings in society. The social interactions established by the participants strongly influenced the adherence to the ARVT, in addition to functioning as a tool to improve their autonomy in their self-care, as they seemed to feel more trustworthy when the support network were more well-structured ${ }^{(9-10)}$.

The coping strategies, such as the emotional coping shared with relatives, imply support that is a protective factor against the development of psychosocial disorders, such as depression and suicidal ideation, since these disorders, in addition to anxiety, were predominant in some studies, having a significant negative impact on the adherence to the ARVT, as well as in the quality of life $\mathrm{e}^{(5-6,20)}$.

Many interviewees mentioned harmful activities, that put their health in danger, such as the use of legal and illegal drugs, prostitution, and the prejudice against living with a different appearance. Healthy living, for patients with HIV/AIDS, refers to the unique way in which people live and interact, their experience of living going far beyond the causal determinism of the health-disease process, while the biomedical model is a producer/ product of the moral regulative character, with collective beliefs, values, desires, and standards ${ }^{(16,18)}$.

If, on one hand, the modern development of the health sector allowed for advances that led to an increased survival rate, it also was an imperative device for population control, since it determined existential norms and parameters considered to be accepted, valued, and normal. This is how the AIDS epidemic becomes noteworthy, not due to a desire to confront it, but in the delimitation of behaviors, imputing those considered to be normal(18).

As a result, the survival of the person who lives with HIV/AIDS is not only led by the regular use of ARVT or lack thereof. It goes beyond, and other issues are important forces that stimulate their living. Since we are beings who use symbols in which we trust, we do not use to answer to stimuli in an automatic or direct way. In reality, we attribute meaning to the stimuli, and then, we act in accordance with these meanings. Human beings differ from animals because they decide how to act based on how they interpret stimuli in a certain context, that is, they respond to things, events, objects, persons or experiences based on the meanings attributed to them ${ }^{(21)}$.

Therefore, a symbol does not exist if there are no intentionality and meaning underlying its use, and its construction is 
elementary based on interactions between people, which leads one to presume that symbols can assume different meanings ${ }^{(9-10)}$. Considering the ever changing character of this epidemic, and the ways in which the social interactions themselves take place, it is necessary to assume that the knowledge about empirical realities is a dynamic and unfinished process.

The meaning attributed to the process of living with HIV/AIDS by some of the interviewees refers, in many statements, to the "fear" in regard to infections by HIV. This becomes clear especially in the group of outpatient clinic patients, who often mentioned their fear to expose their health conditions to others, fear in regard to the stigma faced when the infection became apparent, and fear to have relations with others due to the risk of infecting them.

From an interactionist perspective, the self of the interviewees is in conflict, in a duality that confronts what they think/desire to what they think society demands. They evoke the "I", which is the impulsive tendency of the individual, with gestures that indicate distress and uncontrollable crying, as they talk about the fear that victimizes them, even in the case of those who were not hospitalized. The "Me" is the generalized other, that is, the one that guides the control over the expressed behavior in an organized way, for the individual to feel as a concrete, stable, and controled part of society. The "Me" stands out, thus, as an expression of feelings that normally human beings "hide" in daily life, such as fear and shame, to be able to remain inserted in society and live daily, using "masks" that allow them to show a supposed organization and control over their lives ${ }^{(9-10)}$.

The feeling of not being a part of society may be related to the loss of control due to the clinical manifestation of the disease or to the inability to continue taking medication, thus increasing the susceptibility to illnesses. In this regard, both physical and psychosocial disorders are considered, as expressed by the reaction of the generalized other (the "Me"), represented by the "I" that, in the experience of those interviewed, cries, becomes unarticulated, wither, and suffers. These people consider that the normal, stable, and controlled "Me", to live in society, is expressed by the absence of disease.

In the situations in which they decided to interrupt the medication intake, which are expressed by feelings of well-being and normality, it can be noted that, in the SI, this action, which did not depend on negotiations with others, led to an interactive action directed to the self, considering the interpretation of the meanings of feeling healthy and, therefore, capable of interrupting the use of the ARVT.Thus, the symbolic character of this action is related to freedom and autonomy. This attitude is generated by a mental process that culminated in interrupting the ARVT by some participants, in different moments of their lives, and can be seen as self-negligence, which affects the adherence to the $\operatorname{ARVT}^{(4,21)}$.

For interactionists, the notion that society is formed by people who interact symbolically, and that their structures are human products, is in accordance with the fact that we do not need to reproduce what we see, listen, and practice daily, nor the social meanings that we receive as a heritage, since, through constant interaction, we can attribute new meanings to everything and everyone, which implies in remodeling and transforming society. This is how, living in constant interaction, people can construct, deconstruct, and create new circumstances and actions according to the meaning attributed to each social act, due to the symbolic capacities of the human being. The things each social actor does depends, in part, on the actions of others, but each action is determined by their own volition ${ }^{(9-10,21)}$.

\section{Study limitations}

The interviewees seem to perceive the possibility of being diseased in a potentially more negative way than this event may have been perceived by a person who was not infected, as if those who are not affected by HIV never became diseased. This increased power attributed to the state of being diseased is due to a hyper-valorization of the healthy being. This hypothesis, in the scope of the development of the GT, is a limitation of this study, since it points towards the need to construct other sample groups to understand the phenomenon, considering all possible social interactions.

\section{Contributions for the field of nursing and health}

Living with HIV/AIDS is a social phenomenon in which it is not possible to disconnect the process of adapting to the disease from the social relations one (re)constructs during life. This phenomenon influences everyone in society and also involves stigmatization, rejection, and isolation. It is necessary to invest in the health care of those who struggle to maintain their wellbeing and social inclusion. Resignifying the biopsychosocial needs of people with HIV implies in addressing their primary needs, which have been affected, favoring proactive behavior, acceptance, and resilience, not only in regard to the care that is necessary due to the presence of the virus and to the need to adhere to medication therapies, but also in dealing with social values that reproduce models which can help in self-knowledge. Nurses and other health professionals must know this reality so they can give direction to their actions on the base of previously constructed relations and interactions based on complacency.

\section{FINAL CONSIDERATIONS}

The meanings and significance attributed by people with HIV/ AIDS to the process of living with this virus/disease referred to the confrontation of deleterious actions they already had or developed after the infection, such as the use of drugs and prostitution; the valuing of taking the ARVT medication as a new necessity to stay alive; other actions that often lead them to abandon ARVT when confronted with the feeling that they are not diseased, when immunologically quiescent; reactions such as resilience, which bring them closer to the "normality" instituted by a society that appreciates the healthy, valuing social interactions and networks of health care; and reactions to the prejudicial effects to one's self-image and health state caused by the infection by HIV/AIDS.

When the importance of the networks of care and social support, such as the family, is considered, the meanings also pointed at fragilities in the interactions, due to the stigma and to the prejudice, which increase the demands of biopsychosocial and emotional care, while also increasing the difficulty to self-care and the adherence to medication. 
Thus, depending on the circumstances of the life of each person, which directly influence the meanings attributed, it is possible to refute the hypothesis according to which the patients attended in the outpatient clinic who have no recent history of hospitalizations follow a routine of care that could be related to meanings that are different from those from the patients who have the disease already installed and are often hospitalized. This can be determined because even the patients attended in the outpatient clinic reported to take harmful actions, which expose them to the disease.

\section{FUNDING}

This study was financed in part by the Coordenação de Aperfeiçoamento de Pessoal de Nível Superior - Brasil (CAPES) - Finance Code 001.

\section{REFERENCES}

1. Abadiga M. Depression and its associated factors among HIV/AIDS patients attending ART clinics at Gimbi General Hospital, West Ethiopia. 2018. BMC Res Notes. 2019;12:527. https://doi.org/10.1186/s13104-019-4553-0

2. Kaneez S. Depression and coping mechanism among HIV/AIDS patients under anti-retroviral therapy. Indian J Soc Psychiatry. 2016;32(2):149-53. https://doi.org/10.4103/0971-9962.181098

3. Ooms G, Kruja K. The integration of global HIV/AIDS response into universal health coverage: desirable, perhaps possible, but far from easy. Global Health. 2019;15:44. https://doi.org/10.1186/s12992-019-0487-5

4. Mbuagbaw L, Hajizadeh A, Wang A, Mertz D, Lawson DO, Smieja M, et al. Overview of systematic reviews on strategies to improve treatment initiation, adherence to antiretroviral therapy and retention in care for people living with HIV: part 1. BMJ Open. 2020;10(9):e034793. https:// doi.org/10.1136/bmjopen-2019-034793

5. Brewer R, Hood KB, Hotton A, Moore M, Spierldenner A, Daunis C, et al. Associations between experienced HIV stigma, resulting consequences, and the HIV care continuum: moderating effects of two resilience characteristics among persons living with HIV (PLWH) in Louisiana. J Racial Ethn Health Disparities. 2020;1-14. https://doi.org/10.1007/s40615-020-00925-1

6. Stockton MA, Udedi M, Kulisewa K, Hosseinipour MC, Gaynes BN, Mphonda SM, et al. The impact of an integrated depression and HIV treatment program on mental health and HIV care outcomes among people newly initiating antiretroviral therapy in Malawi. PLoS One. 2020;15(5):e0231872. https://doi.org/ 10.1371/journal.pone.0231872

7. Weeks MR, Lounsbury DW, Li J, Hirsch G, Berman M, Green HD, et al. Simulating system dynamics of the HIV care continuum to achieve treatment as prevention. PLoS One. 2020;15(3):e0230568. https://doi.org/10.1371/journal.pone.0230568

8. Dave S, Peter T, Fogarty C, Karatzas N, Belinsky N, Pai NP. Wich community-based HIV initiatives are effective in achieving UNAIDS $90-90-90$ targets? a systematic review and meta-analysis of evidence (2007-2018). PLoS One. 2019;14(7):e0219826. https://doi.org/10.1371/journal. pone.0219826

9. Blumer H. Symbolic interactionism: perspective and method. Englewood Cliffs (NJ): Prentice-Hall; 1969.

10. Sandstrom KL, Martin DD, Fine GA. Símbolos, selves e realidade social: uma abordagem interacionista simbólica à psicologia social e à sociologia. Rio de Janeiro: Vozes; 2016.

11. Corbin J, Strauss A. Basics of qualitative research: techniques and procedures for developing Grounded Theory. Thousand Oaks (CA): SAGE; 2015.

12. Santos JLG, Cunha KS, Adamy EK, Backes MTS, Leite JL, Sousa FGM. Data analysis: comparison between the different methodological perspectives of the Grounded theory. Rev Esc Enferm USP. 2018;52:e03303. https://doi.org/10.1590/S1980-220X2017021803303

13. Tran BX, Phan HT, Latkin CA, Nguyen HLT, Hoang CL, Hoang CL, et al. Understanding global HIV stigma and discrimination: are contextual factors sufficiently studied?. Int J Environ Res Public Health. 2019;16(11):1988. https://doi.org/10.3390/ijerph16111899

14. Zepeda KGM, Silva MM, Santos DCL, Gaspar RB, Trotte LAC. Management of nursing care in HIV/AIDS from a palliative and hospital perspectives. Rev Bras Enferm. 2019;72(5):1234-50. https://doi.org/10.1590/0034-7167-2017-0431

15. Saunders B, Sim J, Kingstone T, Baker S, Waterfield J, Bartlam B, et al. Saturation in qualitative research: exploring its conceptualization and operationalization. Qual Quant. 2018;52(4):1893-907. https://doi.org/10.1007/s11135-017-0574-8

16. Elion RA, Kabiri M, Mayer KH, WohI DA, Cohen J, Beaubrun AC, et al. Estimated impact of targeted pre-exposure prophylaxis: strategies for men who have sex with men in the United States. Int J Environ Res Public Health. 2019;16(9):1592. https://doi.org/10.3390/ijerph16091592

17. Abreu PD, Araújo EC, Vasconcelos EMR, Ramos VP, Moura JWS, Santos ZC, et al. Social representations of transsexual women living with HIV/ AIDS. Rev Bras Enferm. 2020;73(3):e20180390. https://doi.org/10.1590/0034-7167-2018-0390

18. Joint United Nations Programme on HIV/AIDS. 90-90-90: uma meta ambiciosa de tratamento para contribuir para of fim da epidemia de AIDS [Internet]. Brasília, DF: UNAIDS; 2017 [cited 2018 Feb 2]. Available from: http://unaids.org.br/wp-content/ uploads/2015/11/2015_11_20_UNAIDS_TRATAMENTO_META_PT_v4_GB.pdf

19. Jesus GJ, Oliveira LB, Caliari JS, Queiroz AAFL, Gir E, Reis RK. Difficulties of living with HIV/Aids: obstacles to quality of life. Acta Paul Enferm. 2017;30(3):301-7. https://doi.org/10.1590/1982-0194201700046 
20. Foresto JS, Melo ES, Costa CRB, Antonini M, Gir E, Reis RK. Adhrence to antiretroviral therapy by people living with HIV/AIDS in a municipality of São Paulo. Rev Gaucha Enferm. 2017;38(1):e63158. https://doi.org/10.1590/1983-1447.2017.01.63158

21. Edalamaw A, Mekonnen M, Geremew D, Yehualashet FA, Tesera H, Habtewold TD. HIV/AIDS treatment failure and associated factors in Ethiopia: meta-analysis. BMC Public Health. 2020;20:82. https://doi.org/10.1186/s12889-020-8160-8 